\title{
Effects of Pecan Bacterial Leaf Scorch on Growth and Yield Components of Cultivar Cape Fear
}

\author{
R. S. Sanderlin and K. I. Heyderich-Alger, Louisiana State University Agricultural Center, Pecan Research-Exten- \\ sion Station, Shreveport 71135
}

\begin{abstract}
Sanderlin, R. S., and Heyderich-Alger, K. I. 2003. Effects of pecan bacterial leaf scorch on growth and yield components of cultivar Cape Fear. Plant Dis. 87:259-262.

Pecan bacterial leaf scorch (PBLS) recently was recognized to be caused by the bacterium $X y$ lella fastidiosa. The objective of this work was to compare certain tree growth and yield components of trees with and without PBLS. The evaluations were made for 3 years (1999 to 2001) on the disease-sensitive cv. Cape Fear. At nut maturity (October) each year, the number of leaves and leaflets and the leaflet weight were significantly smaller on terminals from trees with leaf scorch than on terminals from trees not infected with $X$. fastidiosa. Similar amounts of defoliation occurred on bearing and nonbearing terminals. The symptomatic terminals averaged $58 \%$ fewer leaflets at the end of the growing season. The weight of terminals from diseased trees was significantly lower in 2 of the 3 years for nonbearing terminals compared with similar terminals from uninfected trees. Terminals of infected trees generally were not significantly shorter than terminals of uninfected trees. The weight of the nuts from terminals with leaf scorch was lower than the weight from uninfected trees each year. The primary effect was on kernel development, which averaged $16 \%$ lower weight. Phosphorus concentration was slightly but significantly lower in infected leaflets during October in three of six comparisons. There were no other consistent differences in the concentration of nine other elements in leaflets between diseased and uninfected terminals. PBLS is capable of causing economically significant yield reductions. Because the disease is chronic, the potential yield reduction over the life of a tree is large on disease-sensitive trees.
\end{abstract}

Additional keywords: Carya illinoinensis, xylem-limited bacteria

Cv. Cape Fear is a popular pecan cultivar that has been planted in commercial orchards throughout the southeastern United States. This cultivar originated as a seedling of cv. Schley and is valued in both retail and wholesale trade because of its high yield, bright kernel color, and nut size (19). Cv. Cape Fear exhibits a tendency to develop foliar scorch that often begins in midsummer and increases in severity through the remainder of the crop season. The cause of this problem recently was demonstrated to be the bacterium Xylella fastidiosa, and the disease was named pecan bacterial leaf scorch (PBLS; 16). A symptom of PBLS is necrosis of leaflets beginning at the tips and margins; necrotic leaflet tissue usually has tan to light brown coloration. The necrosis quickly progresses in an unbroken pattern toward the base and midribs, and leaflets generally abscise soon after symptoms appear. Symptoms on the compound leaves frequently begin on the older leaflets and advance toward the leaf

Corresponding author: R. S. Sanderlin

E-mail: rsanderlin@agctr.1su.edu

Accepted for publication 2 October 2002.

Publication no. D-2003-0110-02R

(C) 2003 The American Phytopathological Society apex. Leaflet defoliation follows this same pattern so that rachises may be nearly bare with only the youngest leaflets still attached. Symptoms can develop throughout a tree or be confined to individual limbs (16).

Even though this disease is prevalent on cv. Cape Fear, no data have been presented about the amount of defoliation caused by PBLS or the effect on crop yield or quality. The objectives of this work were to quantify the defoliation caused by $X$. fastidiosa infection on cv. Cape Fear and determine if the disease affected tree growth or nut production.

\section{MATERIALS AND METHODS}

Orchard description and experimental design. The orchard used in this study was located in Natchitoches Parish, Louisiana. When the study began, the orchard was about 25 years old and covered an area of approximately 20 ha on Moreland clay soil. The orchard was composed of five cultivars: Cape Fear, Stuart, Mahan, Desirable, and Elliott, with one cultivar in each row. There were a few seedling trees randomly located throughout the planting. Trees were spaced $9.1 \mathrm{~m}$ apart in rows with $18.3 \mathrm{~m}$ between rows. The orchard had been managed for commercial production since its establishment and nutritional and pest control production practices were continued through the course of this test.
Ten cv. Cape Fear trees with severe PBLS symptoms were tagged in the summer of 1999. Tagged, diseased trees were scattered throughout the southern twothirds of the orchard. Ten trees without symptoms in the same area of the orchard were tagged and used for comparison. During August 1999, leaves from the 20 test trees were assayed for $X$. fastidiosa using a commercially available enzymelinked immunosorbent assay (ELISA) kit (Agdia, Elkhart, IN).

Collection and measurement of samples for determination of effects on defoliation, terminal growth, and yield components. Following shuck split in October, 10 samples of the current year's nonbearing terminal growth were cut from each tree and placed in a paper bag along with the leaves. Any leaves or leaflets that fell off the stems during collection were considered abscised and not collected. To determine if PBLS affected bearing and nonbearing terminals differently, five nutbearing terminals were collected from each of the trees. All terminals were cut from the outer circumference of the trees at a height of 1 to $2 \mathrm{~m}$ from the ground. Only terminals with a single flush of leaves were sampled. All of the samples from X. fastidiosa-infected trees had symptoms of PBLS when collected. Twenty-five nuts were collected from opened shucks of each tree. Nuts from diseased trees were taken from terminals with symptoms. Sample collection dates were as follows: nonbearing terminals 20 October, bearing terminals 22 October, nuts 20 October 1999; nonbearing terminals 17 October, bearing terminals and nuts 23 October 2000; and nonbearing terminals 12 October, bearing terminals and nuts 17 October 2001. The same trees and sampling procedures were used each year.

Samples were transported to the Louisiana State University Agricultural Center, Pecan Research-Extension Station and allowed to dry at room temperature for at least 4 weeks prior to data collection. The number of rachises and leaflets in each bag were recorded and stem length and weight were measured. The nuts were dried at room temperature for 2 months before weighing. The shells were removed and the kernel weight recorded.

Leaflet elemental composition. All of the leaflets from the sample terminals of each tree were combined and ground in a Wiley Mill to prepare for elemental analy- 
sis. Some of the leaflets of $X$. fastidiosainfected terminals had PBLS symptoms and some leaflets did not. The sample from the nonbearing terminals was composed of the leaflets from 10 terminals, and the nutbearing terminal sample of each tree was composed of the leaflets of 5 terminals. The concentrations of 10 elements were determined: calcium, copper, iron, magnesium, manganese, nitrogen, phosphorus, potassium, sulfur, and zinc. Analysis was sity Agricultural Chemistry Lab with the leaflet samples from 1999 and 2000. The 2001 samples were analyzed by the Louisiana State University Agricultural Center Agronomy Department. Tissue analysis was done with inductivity coupled plasma and emission spectroscopy.

Standard analysis of variance was used for all data analyses in this study. Mean comparisons were made with a $t$ test.

\section{RESULTS}

PBLS incidence. In 1999, the 10 test trees with PBLS symptoms tested positive for X. fastidiosa using ELISA, and the 10 trees without symptoms were negative for the bacterium. During each year of the study, there was a high level of PBLS severity on the $X$. fastidiosa-infected trees and disease symptoms were prevalent throughout the canopy of each tree. No PBLS symptoms were seen on any of the uninfected trees. In October of the final test year (2001), leaves were collected from each tree for serological assay for the bacterium. As in the first year of the test, the 10 trees with PBLS symptoms were positive for $X$. fastidiosa and the 10 trees without symptoms were negative for the carried out by the Louisiana State Univer-

bacterium, suggesting that the pathogen had not moved into any of the uninfected trees during the 3 years of the study. In 2001, an unidentified leaf spot occurred on all of the test trees in late summer. It could not be determined if this leaf spot affected defoliation.

Effects of PBLS on defoliation, terminal growth, and yield components. At the end of each crop season, the terminals with PBLS had significantly greater premature defoliation of leaves and leaflets than trees without PBLS (Table 1). The numbers of leaves and leaflets on the terminals of trees without PBLS were similar for bearing and nonbearing stems. The amount of defoliation that occurred on diseased terminals also was similar in 2000 and 2001 for both terminal types. In 1999, the bearing terminals had $32 \%$ more premature defoliation of entire leaves and 19\% more total leaflet loss than the nonbearing stems. During the 3-year period, compound leaf abscission varied from 23 to $56 \%$. Diseased terminals had 67,66 , and $41 \%$ more leaflet defoliation in the three successive years of the test (Table 1). The average weight of the dried leaflets (calculated from total leaflet weight and numbers) from the terminals with and without $X$. fastidiosa was similar each year, indicating that PBLS did not affect the growth of the leaflets. The 3-year average dry weight per leaflet was $0.21 \mathrm{~g}$ for the uninfected leaflets and $0.22 \mathrm{~g}$ for the infected leaflets.

Infected stems of nonbearing terminals were significantly lower in weight in 2 years and lower $(P=0.09)$ in the other year than nonbearing stems from uninfected trees, with an average weight reduction of $24 \%$ (Table 1). Bearing terminals

Table 1. Comparison of leaves, leaflets, and terminals from trees with and without pecan bacterial leaf scorch (PBLS) ${ }^{\mathrm{a}}$

\begin{tabular}{|c|c|c|c|c|c|c|}
\hline \multirow[b]{2}{*}{ Variable $^{b}$} & \multicolumn{2}{|c|}{1999} & \multicolumn{2}{|c|}{2000} & \multicolumn{2}{|c|}{2001} \\
\hline & NBT & PBT & NBT & PBT & NBT & PBT \\
\hline \multicolumn{7}{|c|}{ Leaves/terminal } \\
\hline No PBLS & 7.4 & 7.7 & 9.0 & 6.6 & 8.0 & 7.2 \\
\hline With PBLS & 5.6 & 3.4 & 5.0 & 3.1 & 6.1 & 5.2 \\
\hline Probability & 0.0001 & 0.0001 & 0.0001 & 0.0001 & 0.0077 & 0.0444 \\
\hline \multicolumn{7}{|c|}{ Leaflets/terminal } \\
\hline No PBLS & 70.3 & 74.7 & 84.9 & 60.4 & 65.6 & 61.0 \\
\hline With PBLS & 30.3 & 18.1 & 27.5 & 21.5 & 39.8 & 35.0 \\
\hline Probability & 0.0001 & 0.0001 & 0.0001 & 0.0001 & 0.0067 & 0.0177 \\
\hline \multicolumn{7}{|c|}{ Leaflet weight (g) } \\
\hline No PBLS & 12.0 & 13.6 & 19.3 & 12.0 & 14.5 & 14.8 \\
\hline With PBLS & 5.4 & 3.6 & 6.4 & 4.8 & 9.0 & 8.8 \\
\hline Probability & 0.0001 & 0.0001 & 0.0001 & 0.0001 & 0.0130 & 0.0337 \\
\hline \multicolumn{7}{|c|}{ Terminal length $(\mathrm{cm})$} \\
\hline No PBLS & 12.5 & 14.6 & 16.1 & 11.4 & 16.4 & 13.9 \\
\hline With PBLS & 11.8 & 13.7 & 14.2 & 13.4 & 13.3 & 11.2 \\
\hline Probability & 0.3897 & 0.4551 & 0.2499 & 0.1331 & 0.0348 & 0.2096 \\
\hline \multicolumn{7}{|c|}{ Terminal weight $(\mathrm{g})$} \\
\hline No PBLS & 1.4 & 1.6 & 2.2 & 1.5 & 2.0 & 2.0 \\
\hline With PBLS & 1.1 & 1.2 & 1.5 & 1.7 & 1.6 & 1.5 \\
\hline Probability & 0.0858 & 0.0171 & 0.0095 & 0.4191 & 0.0514 & 0.2012 \\
\hline
\end{tabular}

${ }^{\mathrm{a}} \mathrm{NBT}=$ nonbearing terminals, means of 10 terminals from each of 10 trees, and $\mathrm{PBT}=$ pecanbearing terminals, means of 5 terminals from each of 10 trees.

${ }^{\mathrm{b}}$ Probability for means in a column was based on a $t$ test. with PBLS weighed significantly less than uninfected bearing terminals only in 1999. Even though the trend was for PBLS-diseased terminals to be shorter (five of six measurements), the difference was significant only on nonbearing terminals in 2001 (Table 1).

Weight of nuts on terminals with PBLS was significantly lower than that of nuts from trees without the disease in 2000 and 2001 and was lower $(P=0.08)$ in 1999 (Table 2). The major effect was on kernel development, because the percent reduction in kernel weights was higher than the reduction of in-shell weights (Table 2). The difference in kernel weights between nuts from infected and uninfected trees was significant each year. The average in-shell weight was reduced by 10 to $13 \%$ each year. The average kernel weight was reduced by 18,16 , and $14 \%$ in the 3 successive years of the test. This was reflected in a slight reduction of percent kernel weight of nuts from diseased terminals compared to unaffected terminals (Table 2).

Leaflet elemental composition. There were significant differences in element concentrations of leaflets between bearing and nonbearing stems (data not shown). Terminals without nuts tended to have higher elemental concentrations in the leaflets than nut-bearing terminals. However, the data indicated that only phosphorus appeared to be consistently affected by PBLS. Phosphorus was slightly but significantly lower in pecan-bearing terminals in 1999 and nonbearing terminals in 2000 and 2001 with PBLS. It was lower $(P=0.08)$ in pecan-bearing terminals with PBLS in 2001 (data not shown). The nonbearing terminals without PBLS had a mean phosphorus percent of 0.14 and the diseased terminals averaged $0.12 \%$. The percent phosphorus of the nondiseased bearing terminals was 13.3 and was 11.7 for diseased bearing terminals. None of the other nine elements analyzed exhibited a consistent pattern of difference between leaflets with and without PBLS.

Table 2. Effect of pecan bacterial leaf scorch (PBLS) on nut and kernel weight ${ }^{\mathrm{a}}$

\begin{tabular}{clll}
\hline Variable $^{\mathbf{b}}$ & $\mathbf{1 9 9 9}$ & $\mathbf{2 0 0 0}$ & $\mathbf{2 0 0 1}$ \\
\hline Nut wt (g) & & & \\
No PBLS & 7.9 & 9.0 & 9.8 \\
With PBLS & 7.0 & 7.7 & 8.9 \\
Probability & 0.0753 & 0.0038 & 0.0012 \\
Kernel wt (g) & & & \\
No PBLS & 4.4 & 5.0 & 5.2 \\
With PBLS & 3.6 & 4.2 & 4.5 \\
Probability & 0.0176 & 0.0010 & 0.0001 \\
Percent kernel & & & \\
No PBLS & 57.3 & 55.4 & 53.4 \\
With PBLS & 51.3 & 53.9 & 50.7 \\
Probability & 0.2044 & 0.0176 & 0.0124 \\
\hline
\end{tabular}

${ }^{a}$ Means are from a 25-nut sample collected from each of 10 trees with PBLS and 10 trees without PBLS.

${ }^{b}$ Probability for means in a column was based on a $t$ test. 


\section{DISCUSSION}

The trees not infected with Xylella were in the same area of the orchard and intermixed with infected trees. The apparent lack of spread of the pathogen to any of the 10 uninfected trees during the 3-year period of the test suggests that spread of this bacterium in pecan orchards can be slow. Observations from other orchards suggest that the disease often may move slowly from tree to tree within an orchard. If this is the typical trend, it may be possible to reduce the incidence of PBLS in orchards by starting with healthy trees during orchard establishment.

There are numerous reports of premature leaf abscission as one of the symptoms of diseases caused by $X$. fastidiosa $(7,10,13,15)$. However, little if any quantification of the degree of defoliation caused by Xylella infection has been published. This may be because many of the economically important hosts eventually die as a result of the disease $(8,12-15,17)$. Pecan trees are not killed by the bacterium; thus, the amount of defoliation that results from infection is an important measure of the economic importance of the disease.

During rapid kernel development, nuts are high energy sinks, drawing some of the photosynthates from leaves on nut-bearing terminals $(3,5)$. However, few experimental data document the effects of premature defoliation on the current season's pecan crop. In a study involving complete defoliation of very young trees at one point in time, nut weight was not affected unless defoliation occurred before September (23). Two other studies suggested that complete kernel development required a minimum of two to six leaves for each nut on a tree during the rapid kernel formation stage (August to October; 11,18). None of these studies addresses the effect of defoliation that begins in midsummer and accumulates until frost (usually mid-November in Louisiana), such as occurs with PBLS. In this study, severe PBLS disease caused a dramatic premature defoliation on affected terminals of cv. Cape Fear. Over the 3-year period, terminals from trees with PBLS had an average of $58 \%$ more defoliation at the end of the season compared with the uninfected trees. Nuts on diseased terminals were reduced in weight by 10 to $13 \%$ and kernel weight reduced by 14 to 19\%. This represents a significant economic effect of the disease on nut yield. With a mean yield of $1,664 \mathrm{~kg} / \mathrm{ha}(66.7$ trees/ha) for mature cv. Cape Fear trees (S. Dove, 2002, pecan variety information, University of Georgia, Tifton, website), an average $12 \%$ yield loss could reduce income by an average of $\$ 466 /$ ha based on the 10-year average in-shell price from 1989 to 1998 (Federal-State Market News, Thomasville, GA website). The data reported here appear to be the first that relate the effect of progressive leaf loss that occurred over a period of months on nut development.

The greatest damage caused by PBLS may occur as a result of the effect of the defoliation on the succeeding crops. Alternate bearing is a major problem in commercial pecan management systems. It has been documented that premature defoliation accentuates alternate bearing $(18,20)$. Young trees that were completely defoliated on or before 15 September did not set nuts the following year (23). Nut set increased with succeedingly later defoliation dates, but was still significantly less than nut set when trees were not prematurely completely defoliated $(18,20,23)$. These studies on the effects of defoliation on nut set involved leaf removal at one point in time. In reality, leaf diseases such as PBLS tend to cause increasing leaf loss over time, and the previous data may not apply directly to the effect of a leaf loss disease on succeeding nut set.

Although reports of reduced growth and stem dieback caused by Xylella infection are common $(7,9,10,14,15)$, this was not confirmed with pecan. In this study, the mean length of terminals with PBLS was shorter in five of the six measurements; however, generally, the difference was not significantly less than the length of uninfected terminals. The effect of PBLS on terminal length might be limited because most of the current season's terminal growth is completed before the onset of symptoms each year. The reduction in terminal weight may indicate that early leaf loss reduced the carbohydrate storage in the stems following kernel development $(3,21,24)$.

The effects of $X$. fastidiosa infection on the elemental composition of leaves reported from some other plants were not detected with pecan in this study. There was no obvious effect of PBLS on the concentration of potassium, calcium, or magnesium as reported for grape and peach $(4,6)$. Citrus blight disease caused by $X$. fastidiosa is associated with zinc deficiency in the leaves (1). The zinc level of infected pecan leaves was not different from uninfected tissue at the time of the assay. However, phosphorus was consistently slightly lower in the diseased tissue. Reduced phosphorus sometimes is associated with water-stressed leaves $(2,6)$. Elemental leaf concentration varies over time; therefore, multiple sampling periods should be used to evaluate the effect of PBLS on the nutritional status of the foliage.

Severe PBLS can cause significant defoliation from midsummer until a freeze or senescence removes the foliage on $\mathrm{cv}$. Cape Fear. Yield in the current season can suffer a significant economic loss, and it is probable that successive crops are reduced in size. The disease may make trees more susceptible to damage from environmental stresses such as fall freezes (22). The dis- ease is chronic, occurring almost annually; therefore, the yield loss over the productive lifetime of a tree is potentially large. As with most diseases caused by $X$. fastidiosa, there is currently no practical control for PBLS. New cultivars should be screened for susceptibility prior to release. Information is needed on vector identification and susceptibility of other widely grown cultivars and their disease reactions.

\section{LITERATURE CITED}

1. Albrigo, L. G., and Young, R. H. 1981 Phloem zinc accumulation in citrus trees af fected with blight. HortScience 16:158-160.

2. Anderson, P. C., and Odneal, M. B. 1985. Effect of soil profile modification and irrigation on senescence and bud hardiness of young grapes. HortScience 20:749-751.

3. Davis, J. T., and Sparks, D. 1974. Assimilation and translocation patterns of carbon-14 in the shoot of fruiting pecan trees, Carya illinoensis Koch. J. Am. Soc. Hortic. Sci. 99:468-480.

4. Evert, D. R., Gaines, T. P., and French, W. J. 1981. Rickettsia-like bacteria in peach roots preceded development of visual symptoms of phony peach disease and changes in leaf elemental concentrations. J. Am. Soc. Hortic. Sci. 106:780-782.

5. Finch, A. H., and Van Horn, C. W. 1936. The physiology and control of pecan nut filling and maturity. Ariz. Agric. Exp. Stn. Tech. Bull. 62:421-472.

6. Goodin, P. H., DeVay, J. E., and Meredith, C. P. 1988. Physiological responses of Vitis vinifera cv. "Chardonnay" to infection by the Pierce's disease bacterium. Physiol. Mol. Plant Pathol. 32:17-32.

7. Hopkins, D. L. 1989. Xylella Fastidiosa: Xylem-limited bacterial pathogen of plants. Annu. Rev. Phytopathol. 27:271-290.

8. Kitajima, E. W., Bakarcic, M., and FernandezValiela, M. V. 1975. Association of rickettsialike bacteria with plum leaf scald disease. Phytopathology 65:476-479.

9. Kosta, S. J., Tattar, T. A., and Sherald, J. L. 1986. Elm leaf scorch: abnormal physiology in American elms infected with fastidious, xylem-inhabiting bacteria. Can. J. For. Res 16:1088-1091.

10. Lima, J. E. O. de, Miranda, V. S., Hartung, J. S., Brlansky, R. H., Coutinho, A., Roberto, S R., and Carlos, E. F. 1998. Coffee leaf scorch bacterium: axenic culture, pathogenicity, and comparison with Xylella fastidiosa of citrus. Plant Dis. 82:94-97.

11. Marquard, R. D. 1987. Influence of leaf to fruit ratio on nut quality, shoot carbohydrates, and photosynthesis of pecans. HortScience 22:256-257.

12. Mircetich, S. M., Lowe, S. K., Moller, W. J. and Nyland, G. 1976. Etiology of almond leaf scorch disease and transmission of the causal agent. Phytopathology 66:17-24.

13. Monteiro, P. B., Renaudin, J., Jagoueix-Eveillard, S., Ayres, A. J., Garnier, M., and Bové, J. M. 2001. Catharanthus roseus, an experimental host plant for the citrus strain of Xylella fastidiosa. Plant Dis. 85:246-251.

14. Purcell, A. H., Saunders, S. R., Hendson, M., Grebus, M. E., and Henry, M. J. 1998. Causal role of Xylella fastidiosa in oleander leaf scorch disease. Phytopathology 89:53-58.

15. Raju, B. C., and Wells, J. M. 1986. Diseases caused by fastidious xylem-limited bacteria Plant Dis. 70:182-186.

16. Sanderlin, R. S., and Heyderich-Alger, K. I. 2000. Evidence that Xylella fastidiosa can cause leaf scorch disease of pecan. Plant Dis. 
84:1282-1286.

17. Sherald, J. L., Hearon, S. S., Kostka, S. J., and Morgan, D. L. 1983. Sycamore leaf scorch: culture and pathogenicity of fastidious xylemlimited bacteria from scorch-affected trees. Plant Dis. 67:849-852.

18. Sitton, B. G. 1931. A preliminary report on the relation of foliage to filling of the pecan. Proc. Natl. Pecan Grow. Assoc. Bull. 30:120125.
19. Sparks, D. 1992. Pecan Cultivars, the Orchard's Foundation. Pecan Production Innovations, Watkinsville, GA.

20. Sparks, D., and Brack, C. E. 1972. Return bloom and fruit set of pecan from leaf and fruit removal. HortScience 7:131-132.

21. Wood, B. W., and McMeans, J. L. 1981. Carbohydrate changes in various organs of bearing and nonbearing pecan trees. J. Am. Soc. Hortic. Sci. 106:758-761.
22. Wood, B. W., and Reilly, C. C. 2001. Atypica symptoms of cold damage to pecan HortScience 36:298-301.

23. Worley, R. 1979. Fall defoliation date and seasonal carbohydrate concentration of pecan wood tissue. J. Am. Soc. Hortic. Sci. 104:195199.

24. Worley, R. E. 1971. Effects of defoliation date on yield, quality, nutlet set, and foliage regrowth for pecan. HortScience 6:446-447. 